\title{
On the Possible Significance of High Free Iron Oxide Content in Mabí Clay, a Vertisol from East-Central Puerto Rico
}

\author{
Raul PErez-Escolar and M. A. Lugo-López
}

\section{INTRODUCTION}

Mabi clay is an Aquic Chromudert montmorillonitic-isophyperthermic Vertisol $^{2}(8)^{3}$ which occurs rather extensively throughout the Island on low gentle slopes in close association with the Múcara and related brown medium-shallow and shallow soils of the uplands in the humid east-central Mountain Region. It is derived mainly from material that is, in part, residual and in part colluvial and alluvial.

The Mabi soils are mostly devoted to sugarcane cultivation, which could be completely mechanized on the gentle slopes where this soil occurs. Under proper management fairly good yields can be obtained. The main problem affecting the productivity of this soil is impeded internal drainage. Furthermore, at some times of the year, particularly from December to March, crops grown in this soil suffer from insufficient available moisture supply owing to the fact that the lower parts of the east-central section of the Island are characterized by an erratic, rather limited, rainfall pattern, coupled with soil characteristics conducive to wilting, while still rather high moisture is present in the root zone, but retained under considerable stress.

Although the Mabi soils have been studied rather extensively, this paper provides the first data, to our knowledge, on the high iron content of this type of soil.

1 Associate Soil Scientist and Soil Scientist, Agricultural Experiment Station, Mayagüez Campus, University of Puerto Rico, Río Piedras, P.R. Appreciation is expressed to Dr. Ralph McCracken, Head, Department of Soils, North Carolina State University, Raleigh, N.C., for revising the first draft of this paper and for his valuable suggestions.

2 Vertisol is an order including soils with more than 35 percent clay with expanding lattices that contract and expand with varying moisture, where cracks are formed even down to 20 inches more than once a year. Pressure faces and slickensides occur Chromuderts are Vertisols with high chromes. Aquic indicates poor drainage conditions and mottling with low chromes. Montmorillonite is a clay mineral with 2:1 expanding lattices. Isohyperthermic conditions occur when the differences in mean soil temperature at 20 inches depth between summer and winter is of the order of $9^{\circ} \mathrm{F}$. and mean annual temperature is not less than $71.6^{\circ} \mathrm{F}$.

Numbers in parentheses refer to Literature Cited, pp. 51-2. 


\section{SOIL MORPHOLOGY}

For the morphological studies two pits 4 feet wide, 3 feet long, and 6 feet deep were dug. Information was secured on number of horizons, thickness, color, and apparent texture and structure.

A soil profile was studied at the Buonomo farm near the Gurabo-Caguas road. The slope of the field was about 3 percent. The vegetation consisted mostly of native carpet and Bermuda grasses. Results were as follows:

0-10 inch Dark reddish-brown silty clay with some small stone fragments. Fairly well-developed medium fine fragmental-blocky structure.

10-20 inch Dark reddish-brown, silty clay with very little mottling. Fairly dense, distinct fragmental-blocky structure.

20-30 inch Structure coarser than above, became more massive with depth.

30-38 inch Sandy clay layer, rather loose.

36-48 inch Clay layer, tight.

48-60 inch + Very dense clay layer.

Another profile of Mabi, poorly drained phase, was examined near the road from Las Torres to Las Piedras. The slope of the field was about 2 percent. The field had a dense stand of Para grass. Results were as follows:

0-9 inch Dark-brown mottled clay loam with dark iron and manganese concretions.

9-21 inch Sandy clay loam. Mottled from almost white to almost black, predominantly white, pale color. Also grayish-brown. Lower part began to change to reddish-yellow. Structure almost massive except for old root holes.

21-36 inch Sandy clay loam. Highly mottled white, yellowish-brown, and black. Structure almost massive. May be tightest layer of profile.

36 inch + Water-bearing sandy layer.

\section{SOIL PROPERTIES}

According to Jeffries, et al. (3), Mabí clay contains from 24 to 31 percent of clay particles, increasing with depth. The cation-exchange capacity ranges from 31 to 34 meq. $/ 100 \mathrm{~g}$. of dry soil. The clay minerals are of the montmorillonitic type (predominating beidellite and some illite) with small amounts of kaolinite. Feldspars of the oligloclase and albite varieties are relatively high in abundance particularly in the upper layers. The Mabi is nonacid or slightly acid, relatively high in organic-matter content and rather fertile.

Lugo-López, et al., (5) gave data on bulk density, hydraulic conductivity, and other soil properties measured under laboratory conditions on a number of undisturbed Mabi soil cores ${ }^{4}$ obtained from the aforementioned

${ }^{4}$ Undisturbed soil cores were taken by using a Kelley soil-sampling machine (4). Hydraulic conductivity measurements were made in these cores by recording the rate at which water moved through a column of saturated soil at a known head. In this 
profiles in a more extensive study of the soil of east-central Puerto Rico.

Bulk density ranged from 1.27 in the upper layer to 1.39 g./c.c. in the 20 to 26-inch layer of Mabi silty clay, and from 1.43 in the 0-9 inch layer to $1.57 \mathrm{~g}$./cc. in the 21 - to 28 -inch layer of the clay loam. Only 0.6 and 1.5 percent of the water retained by the soil when all pores are filled is removed in 15 minutes when samples were subjected to $60-\mathrm{cm}$. tension in the silty clay and clay loam, respectively, at the tightest layers.

A very rapid hydraulic conductivity was measured in the upper 8-inch layer of Mabí silty clay, probably resulting from the many channels and root holes observed while sampling. It falls sharply to moderately rapidly in the next layer and to very slow (0.028) when the 20 - to 26 -inch layer is reached. Permanent wilting occurs while the soil still retains a relatively large amount of water ( 25 to 30 percent) thus reducing its available water supply. The measurements made indicate a reliable storage reservoir of 3.65 inches of water in the upper 2 feet of the profile. Assuming the same storage capacity for the next 10 inches, the crop root-zone will have 5.21 inches of water available for crops. Similar calculations for the Mabi clay loam profile show that this soil can store at a given time in readily available form approximately 7.36 acre-inches of water in the upper 3 feet where the bulk of the roots of crop plants are generally found.

According to field infiltration tests, using the Nelson and Muckenhirn method (6), the Mabí soils range from slow to moderate in their infiltration capacity at the eighth-hour run. If adequate artificial drainage is not provided, water stands on the soil surface for several days during rainy periods, owing to the slow downward movement of moisture.

In general, small pores predominate in the root-zone of these heavy-textured Mabi soils, hence the sluggish water movement and consequent slow rate of air circulation in the profile.

An attempt was made to improve the internal drainage properties of this soil, and also its capacity for water storage at lower depths, by the use of vertically mulched sugarcane bagasse at 10 -foot intervals, and 30 inches

measurement special equipment was used, as described by Smith, Furhiman, and Silva (r). Quick drainage was determined by taking the saturated core to a Buckner funnel, setting up a $60-\mathrm{cm}$. tension, and measuring the water drained out at the end of 15 minutes. The water removed and retained at $\mathrm{pF} 1.78$ was measured by bringing the soil cores to equilibrium with a $60-\mathrm{cm}$. tension and determining the variation in weight of the core. Water remaining at $\mathrm{pF} 2.7$ and $\mathrm{pF} 4.2$ was determined by submitting saturated soil samples to pressures of $1 / 2$ and 15 atmospheres, respectively. The maximum saturation was calculated from the above data. The soil core was finally dried in the oven at $110^{\circ} \mathrm{C}$. As the samples used had a definite known volume, the bulk density of the soil was calculated by dividing the net dry weight of soil by its original volume. 
depth in an experimental field at the Gurabo Substation. This has resulted in significantly higher cane yields of the order of 5 tons per acre.

\section{PRESENCE AND SIGNIFICANCE OF IRON OXIDES}

When the collector drain, 3 feet deep, was dug at the vertical mulching experiment the formation of granular aggregates on the walls of the drain was noticed. They varied in size from $1 \mathrm{~mm}$. to nearly 1 inch. The striking reddish tincture of these aggregates, which were originally part of a large unaggregated gray soil mass, attracted our attention. This change in color must have resulted from the oxidation of ferrous material that had been reduced by marked anaerobic conditions which generally must prevail in the subsoil.

The soil aggregates of 2 to $1 \mathrm{~mm}$. in size were separated and a rather high stability in water of the order of 55 percent was measured by the method developed by Bryant, Bendixen, and Slater (1). In order to determine the possibility that these aggregates might disrupt again and return to thier original massive form, 10 -inch columns of these soil aggregates were subjected to a cycle of six periods of wetting and drying. At the end of the sixth period the soil columns' hydraulic conductivity was still about 3 inches per hour.

Considering the red color developed by the aggregates upon exposure to the weathering agents, and the fact that Mabi clay is in the midst of the zone where Ultisols ${ }^{5}$ prevail, the free-iron oxide content of 10 subsoil samples of Mabi clay was determined by using the Jeffries method (F) in an effort to make a comparison with the content of this material in a typical Ultisol. It is well known that free iron oxides are largely responsible for the excellent structure of Ultisols.

The mean free-iron oxide contents in percentage, of 10 samples,with the range of values was: Mean, 14.4; low, 12.6; high, 15.9.

The average, 14.4 percent, compares quite favorably with the 13-percent content of this material present in Cialitos clay, ${ }^{6}$ a typical Ultisol of Puerto Rico. It appears that, to a certain extent, this soil has been strongly influenced by the same genetic process of soil formation as the Ultisols. This would account for the rather high amount of free-iron oxides.

This finding for the Mabi clay, which may also be true for similar soils, points to the possibility of deep plowing as a means of mechanically creating a structure which can be further stabilized by a natural conditioner

- Order including soils with an argillic horizon with less than 35-percent base saturation, decreased with depth. It has clayskins and a well-developed structure with a cation exchange capacity ranging between 16 and 24 meq. $/ 100 \mathrm{~g}$. of dry soil.

- Pérez-Escolar, R., Unpublished data, Department of Soils, Agr. Exp. Sta., Univ. P. R. 
already present in them, namely, free iron oxides. Thus, the high iron content may be advantageously employed to improve the physical properties of this soil and thereby enhance its productivity.

It appears that these soils are apparently quite different from U.S. mainland soils of the same classification in this respect. ${ }^{7}$

\section{SUMMARY}

Data are given here on the free iron oxide content of Mabí clay, an Aquic Chromudert montmorillonitic-isophyperthermic Vertisol from east-central Puerto Rico. A mean value of 14.4 percent was obtained with a high of 15.9 and a low of 12.6. These values are, as compared with the 13-percent average content of free iron oxides in Cialitos clay, those of a typical Ultisol. Probably the same genetic process was involved to some extent in the formation of these soils. There are definite indications that this high iron content can be of value in stabilizing mechanically created soil structure.

\section{RESUMEN}

Se presentan aquí datos sobre el contenido de óxidos de hierro en su estado libre en un suelo Mabí arcilloso de la sección oriental central de Puerto Rico, orden Vertisol, grupo Aquic Chroumudert, isophipertémicomontmorilonítico. Se obtuvo un valor promedio de 14.4 por ciento, con uno máximo de 15.9 y uno mínimo de 12.6. Estos valores se comparan con el de 13 por ciento de óxidos de hierro que contiene el suclo Cialitos arcilloso, el cual es un Ultisol típico. Probablemente, el mismo proceso genético ha estado envuelto en cierta medida en la formación de estos dos suelos. Hay indicaciones definidas de que este alto contenido de hierro puede sur un factor valioso para estabilizar la estructura del suelo, según se vaya creando mecánicamente en el curso de las operaciones agrícolas.

\section{LITERATURE CITED}

1. Bryant, J. C., Bendixen, T. W., and Slaten, C. W., Mensurement of water stability of soils, Soil Sci. 66: 341-5, 1948.

2. Jeffries, C. D., A rapid method for the removal of free iron oxide in soils prior to petrographic analysis, Soil Sci. Soc. Amer. Proc. 11: 211-12, 1946.

3. Jeffries, C. D., Bonnet, J. A., and Aburna, F., The constituent minerals of some soils of Puerto Rico, J. Agr. Univ. P.R. 37(2): 114-39, 1953.

4. Kelley, O. J., Hardman, J. A., and Jennings, I). J., A soil sampling machine for obtaining 2-, 3-, and 4-inch diameter cores of undist urbed soil to a depth of feet, Soil Sri. Soc. Amer. P'roc. (1947) 12: 85-7, 1948.

5. Lugo-López, M. A., Martínez, M. B., and Riera, A. R., Morphological and physico chemical properties of various tropical soils from east-central Puerto Rieo, $J$ Agr. Univ. P.R. 36(2): 167-78, 1952.

6. Nelson, L. B., and Muckenhim, R. J., Field percolation rates of four Wisconsin

7 MeCracken, R., Personal communication, Jan. 13, 1966. See foot note 1. 
already present in them, namely, free iron oxides. Thus, the high iron content may be advantageously employed to improve the physical properties of this soil and thereby enhance its productivity.

It appears that these soils are apparently quite different from U.S. mainland soils of the same classification in this respect. ${ }^{7}$

\section{SUMMARY}

Data are given here on the free iron oxide content of Mabí clay, an Aquic Chromudert montmorillonitic-isophyperthermic Vertisol from east-central Puerto Rico. A mean value of 14.4 percent was obtained with a high of 15.9 and a low of 12.6. These values are, as compared with the 13-percent average content of free iron oxides in Cialitos clay, those of a typical Ultisol. Probably the same genetic process was involved to some extent in the formation of these soils. There are definite indications that this high iron content can be of value in stabilizing mechanically created soil structure.

\section{RESUMEN}

Se presentan aquí datos sobre el contenido de óxidos de hierro en su estado libre en un suelo Mabí arcilloso de la sección oriental central de Puerto Rico, orden Vertisol, grupo Aquic Chroumudert, isophipertémicomontmorilonítico. Se obtuvo un valor promedio de 14.4 por ciento, con uno máximo de 15.9 y uno mínimo de 12.6. Estos valores se comparan con el de 13 por ciento de óxidos de hierro que contiene el suelo Cialitos arcilloso, el cual es un Ultisol típico. Probablemente, el mismo proceso genético ha estado envuelto en cierta medida en la formación de estos dos suelos. Hay indicaciones definidas de que este alto contenido de hierro puede sur un factor valioso para estabilizar la estructura del suelo, según se vaya creando mecánicamente en el curso de las operaciones agrícolas.

\section{LITERATURE CITED}

1. Bryant, J. C., Bendixen, T. W., and Slaten, C. W., Measurement of water stability of soils, Soil Sci. 65: 341-5, 1948.

2. Jeffries, C. D., A rapid method for the removal of free iron oxide in soils prior to petrographic analysis, Soil Sri. Soc. Amer. Proc. 11: 211-12, 1946.

3. Jeffries, C. D., Bonnet, J. A., and Aburña, F., The constituent minerals of some soils of Puerto Rico, J. Agr. Univ. P.R. s7(2): 114-39, 1953.

4. Kelley, O. J., Hardman, J. A., and Jennings, D. J., A soil sampling machine for obtaining 2-, 3-, and 4-inch diameter cores of undisturbed soil to a depth of 6 feet, Soil Sci. Soc. Amer. Proc. (1947) 12: 85-7, 1948.

5. Iugo-López, M. A., Martínez, M. B., and Riera, A. R., Morphological and physicochemical properties of various tropical soils from east-central Puerto Rico, $J$. Agr. Univ. P.R. $36(2):$ 167-78, 1952.

6. Nelson, L. B., and Muckenhirn, R. J., Field percolation rates of four Wisconsin

'McCracken, R., Personal communication, Jan. 13, 1966. See footnote 1. 
soils having different drainage characteristics, $J$. Amer. Soc. Agron. 38(11): 1028-36, 1941.

7. Smith, R. M., Furhiman, D., and Silva, S., Simple procedures for studying soil cores collected with the Kelley (Utah) sampling machine, BPI-SCS Coop, Research Project Report 181, March, 1950.

8. Soil survey staff, Soil classification, a comprehensive system, 7th approximation, USDA-SCS, August 1960.

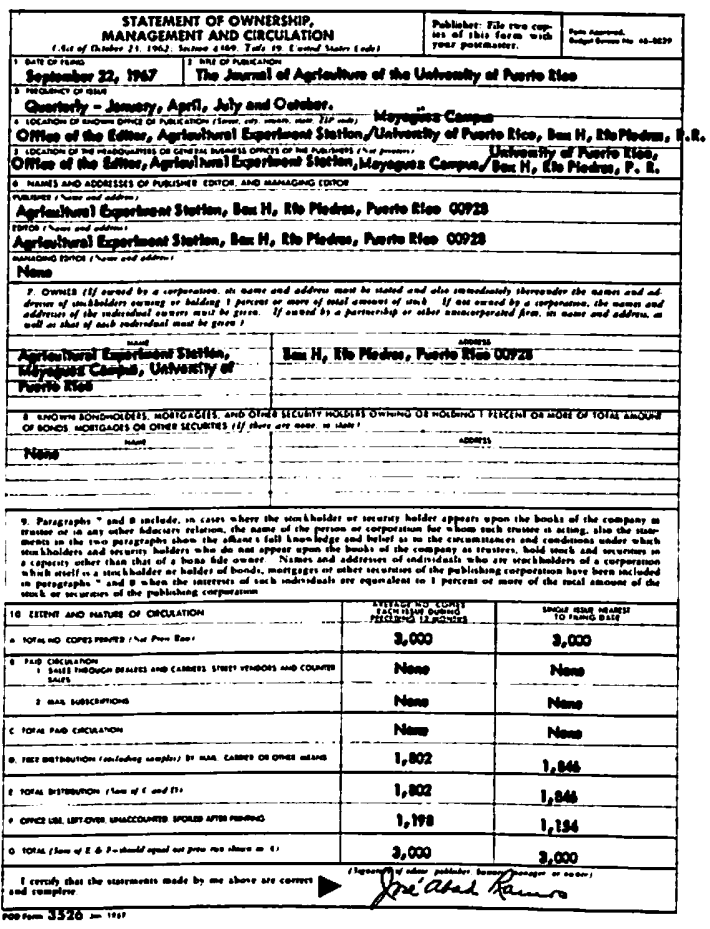

